\title{
How Does National Culture Impact on Consumers' Decision-making Styles? A Cross Cultural Study in Brazil, the United States and Japan
}

\author{
Chan Yie Leng * \\ E-mail address: chanyieleng@yahoo.com \\ Escola Brasileira de Administração Pública e de Empresas/Fundação Getúlio Vargas - EBAPE/FGV \\ Rio de Janeiro, RJ, Brazil.

\section{Delane Botelho} \\ E-mail address: delane.botelho@fgv.br \\ Escola de Administração de Empresas de São Paulo /Fundação Getúlio Vargas - EAESP/FGV \\ São Paulo, SP, Brazil.
}

\begin{abstract}
This empirical article investigates the relationship between national culture and consumer decision-making styles in the purchase of cell phones, a product category that appears to be required by consumers independent of their nationalities. To make the research measurable, we used Hofstede's four cultural dimensions (power distance, uncertainty avoidance, individualism, and masculinity) and Sproles and Kendall's Consumer Style Inventory framework (quality conscious, brand conscious, innovative, recreation, price conscious, impulsive, confused and brand loyal), and tested nine hypotheses through MANOVA in a sample of 108 buyers of the product in Brazil, 104 in the USA, and 107 in Japan, countries ranked in the top ten of the world's largest cell phone market. Factor Analysis via Principal Component Analysis was conducted to examine the suitability of the eight-factor model in observations from each country. The three nationalities and the eight decision-making styles were treated as independent and dependent variables, respectively. Findings showed mixed evidence for the application of Hofstede's cultural dimensions to decision-making styles. Managerial implications and suggestions for future research are presented to help understand the relationship between national culture and consumer decision-making styles.
\end{abstract}

Key words: culture and consumption; global marketing; cross cultural study; consumer decision.

Received 05 May 2009; received in revised form 28 September 2009.

Copyright (C) 2010 Brazilian Administration Review. All rights reserved, including rights for translation. Parts of this work may be quoted without prior knowledge on the condition that the source is identified.

\footnotetext{
* Corresponding author: Chan Yie Leng

Rua Itapeva, 474-907, São Paulo, SP, 01332-000, Brazil.
} 


\section{INTRODUCTION}

The phenomenon of globalization has changed the way people think, behave and do business. Therefore, to achieve successful outcomes in their marketing strategies, marketers should carefully analyze the intrinsic reasons that motivate consumers to respond positively to these marketing stimuli, and how they make choices. Although consumer decision-making style represents a relatively consistent pattern of cognitive and affective responses, national culture has been proved to impact significantly on individual values and attitudes (Hofstede, 1984), and to have a significant influence on consumer decision-making style (Leo, Bennet, \& Hartel, 2005).

This article investigates the relationship between national culture and consumer decision-making styles regarding the purchase of cell phones, a product category that appears to be required by consumers independent of social class, age, gender, race or nationality. It examines how cultural differences impact the way consumers behave during the decision-making process when purchasing the product. To make this research measurable, we have used Hofstede's cultural dimensions (Hofstede, 1984) and Sproles and Kendall's (1986) Consumer Style Inventory [CSI] framework on consumers from Brazil, Japan and USA.

Consumer decision-making style has to do with the mental orientation or approach a consumer has towards making choices (Sproles \& Kendall, 1986). Previous literature has identified ways to characterize consumer decision-making styles: the consumer typology approach seeks to categorize consumers into groups that are related to retail patronage (Westbrook \& Black, 1985); the psychographics/lifestyle approach identifies characteristics related to consumer behavior based on general personality traits, or general needs and values associated with the consumer's general activities, interests or lifestyle (Lastovicka, 1982); the consumer characteristics approach emphasizes the cognitive and affective orientations towards purchasing in consumer decision-making, being of the assumption that consumers possess cognitive and affective orientations to determine their consumer decision-making styles (Fan \& Xiao, 1998; Sproles \& Kendall, 1986). All three approaches are in agreement that consumers respond to the market with basic decision-making styles. However the consumer characteristics approach has been perceived as more explanatory due to its focus on consumers' mental orientation (Lysonski, Durvasula, \& Zotos, 1996), and it will be applied in this article.

Understanding cross-cultural decision-making styles may generate insights to reduce the gap left by international management on whether managers should apply a common or personalized management style to a specific culture. We decided to study the cell phone product because, although its usage, popularity, accessibility and availability vary across countries, it has caused an enormous social impact everywhere. Wherever in use, cell phone technology has altered the way individuals conduct their everyday lives, having extensive implications for the cultures and societies in terms of communication and affecting identities and relationships.

The countries we selected for the empirical research rank in the top ten of the world's largest cell phone market according to the Central Intelligence Agency (2009) (Table 1). Japan and the USA have the highest score in masculinity and individualism, respectively, according to Hofstede's cultural dimensions (Hofstede, 1984). Brazil does not take the first position in any of Hofstede's dimensions, but it deserves special attention since it represents the sixth largest world cell phone market, and thus far no research comparing Brazilian consumers' decision-making styles with other important markets has been found in the scientific literature. 
Table 1:

\section{World Largest Cell-Phone Markets}

\begin{tabular}{cccc}
\hline Rank & Country & Cell phones & $\mathbf{\%}$ \\
\hline 1 & European Union & $466,000,000$ & $21 \%$ \\
2 & China & $461,100,000$ & $21 \%$ \\
3 & USA & $\mathbf{2 3 3 , 0 0 0 , 0 0 0}$ & $\mathbf{1 1 \%}$ \\
4 & India & $166,100,000$ & $8 \%$ \\
5 & Russia & $150,000,000$ & $7 \%$ \\
$\mathbf{6}$ & Japan & $\mathbf{1 0 1 , 7 0 0 , 0 0 0}$ & $\mathbf{5 \%}$ \\
$\mathbf{7}$ & Brazil & $\mathbf{9 9 , 9 1 9 , 0 0 0}$ & $\mathbf{5 \%}$ \\
& World & $\mathbf{2 , 1 6 8 , 4 3 3 , 6 0 0}$ & $\mathbf{1 0 0 \%}$ \\
\hline
\end{tabular}

Note. Source. Central Intelligence Agency (2009). The world factbook. Retrieved March 9, 2009, from http://www.cia.gov/library/publications/the-world-factbook/rankorder/2151rank.html.

The article is structured as follows: this introduction presents the objectives and relevance, next we present the literature review, followed by the empirical research method and results. We conclude by presenting the main implications and suggestions for future research.

\section{LITERATURE REVIEW}

Hofstede's (1984) cultural dimensions and Sproles and Kendall's (1986) Consumer Style Inventory are key features of this research to determine how culture influences the consumer's decision-making style. Culture has been referred to as a set of values, ideas, artifacts and other meaningful symbols that help individuals communicate, interpret and evaluate as members of society (Engel, Blackwell, \& Miniard, 1993). Hofstede (1991) defines culture as the collective programming of the mind which distinguishes the members of one group or category from those of another. Culture is a learned, shared, compelling, interrelated set of symbols whose meanings provide a set of orientations for members of society. These orientations, taken together, provide solutions to problems that all societies must solve if they are to remain viable (Terpstra \& David, 1991).

Despite globalization, people from different nations continue to have their own distinct habits and tastes, their values and norms rooted in their national cultures ( $\mathrm{Zhu}, \mathrm{Quan}, \&$ Xuan, 2006). Usunier (1996) found that there is no empirical evidence to show homogenization of tastes or the appearance of universal price-minded consumer segments. Culture is dynamic and is constantly influenced by changes in the environment in social institutions (legal, political, commercial, etc.) and in an individual's own values. The shared cultural priorities in society help shape the social and economic reward contingencies to which people must adapt in the institutions in which they spend most of their time (families, schools, businesses, etc.) to function smoothly and effectively (Smith \& Schwartz, 1997). People belonging to a particular national culture are subject to the conflicts and compatibilities between their own value structure and the national cultural priorities, so values and attitudes that are opposed to cultural priorities may be discouraged (Schwartz, 1994).

Some marketers have become convinced that the role played by people's values is absolutely central to their personal development, to their actions as citizens and to their behavior as consumers (Lowe \& Corkindale, 1998). A country's culture has long been identified as a key environmental characteristic underlying systematic differences in consumer behavior (Lynn, Zinkhan, \& Harris, 1993). A nation's 
culture may affect the needs consumers satisfy through the acquisition and use of goods (Roth, 1995), but this does not imply that culture is always specific to the country. It can be conceptualized at different levels, and the national level can be only one of them (Dawar \& Parker, 1994).

\section{Hofstede's Four Cultural Dimensions}

Hofstede (1984) characterized national culture into four cultural dimensions: Power Distance Index [PDI], Uncertainty Avoidance Index [UAI], Individualism Index [IDV], and Masculinity Index [MAS]. Those dimensions have been used by many marketing researchers to compare countries in terms of culture (Dawar \& Parker, 1994; Lynn et al., 1993; Roth, 1995).

Power Distance Index [PDI]: Power distance is defined as the extent to which the less powerful person in a society accepts inequality in power and considers it as normal. Inequality exists within any culture, but the degree of it that is tolerated varies among cultures (Hofstede, 1984, p. 390). Hierarchy or unequal power distribution among elements of a society is more common in large power distance cultures. Elements of a society can be referred to as the groups that a member belongs to, such as family, school, workplace and the community. Countries that score high in the power distance index [PDI] tolerate more inequality and have more need for power, wealth, prestige and status (Hofstede, 1991).

In China, for example, a large power distance country, it is not surprising to encounter many types of formalities: at school, students call their teachers by their last names; at the workplace, orders from superiors are accepted by subordinators without objection; and at home, the younger are supposed to respect and listen to the elder. Only few languages in the world, as the case of Chinese, have specific words for: older brother (ge ge), older sister (jie jie), younger brother (di di), and younger sister (mei mei). By contrast, for example, in the workplace, American subordinates and superiors consider each other equal but playing different roles, and each could possibly be switched in the future.

Uncertainty Avoidance Index [UAI]: This measures the degree of tolerance for uncertainty. Cultures with higher UAI are less tolerant of ambiguity and unexpected situations, therefore their societies are structured with stricter rules for social behavior, acting as planned in a very straightforward way. When things do not happen as expected, frustration and intolerance are visible. Societies with low UAI are more willing to accept risks, and their actions incline more towards innovativeness and entrepreneurial spirit.

Individualism [IDV]: This measures the degree to which individuals see themselves and make decisions based on 'I' rather than 'We' (Hofstede, 1991). In individualistic countries, individuals are mainly concerned about their own opinion, they value their personal time to spend on their personal activities, freedom to adjust their work schedule to better suit their lifestyle, and challenge in terms of achieving a personal goal. By contrast, members from collectivistic cultures feel that they belong to a large group and care about the well-being of other members.

Brazilians and Japanese are considered fairly collectivistic cultures, while Americans seem to be individualistic (Hofstede, 1991). In the USA, young people generally leave their parent's house without feeling obliged to look after them when they become older or to consult them before taking decisions.

Masculinity [MAS]: This measures the extent to which a culture has its social roles clearly distributed among its members. Masculine societies value more 'male characteristics' such as assertiveness, competitiveness, success, status. Feminine societies are more inclined to solidarity, modesty, caring and quality of life. Masculine societies largely emphasize those values of wealth, material success, ambition and achievement, and feminine societies emphasize values such as benevolence, equality, caring for the weak and preserving the environment (Hofstede, 1991). Nonetheless, this does not mean that men play in a masculine way and women play in a feminine way; this dimension characterizes the culture of a society as masculine or feminine based on male or female 
characteristics given by nature. Japan is the most masculine culture according to Hofstede's classification, and all the other two countries are considered fairly masculine as well.

Hofstede's cultural dimensions will be used as references to allow the comparison of the three cultures (Brazilian, Japanese and American). Table 2 sums up the three countries score of Hofstede's classification typology.

Table 2:

Hofstede's Cultural Classification by Country

\begin{tabular}{ccccccccc}
\hline Country & PDI & Rank & UAI & Rank & IDV & Rank & MAS & Rank \\
\hline Brazil & 69 & 14 & 76 & $21 / 22$ & 38 & $26 / 27$ & 49 & 27 \\
Japan & 54 & 33 & 92 & 7 & 46 & $22 / 23$ & 95 & 1 \\
USA & 40 & 38 & 46 & 43 & 91 & 1 & 62 & 15 \\
\hline
\end{tabular}

Note. Source. Hofstede, G. (1991). Cultures and organizations: software of the mind (p. 306). London: McGraw-Hill. PDI = Power Distance Index; UAI = Uncertainty Avoidance Index;

IDV = Individualism; MAS = Masculinity.

\section{Consumer Style Index [CSI]}

Several studies on consumer decision process have concluded that consumers follow different styles or rules in making decisions when confronted with choices in the market (Dollinger \& Danis, 1998), and suggested that external factors such as culture may influence the way consumers develop those styles (Canabal, 2002).

Sproles and Kendall (1986) developed the Consumer Style Index [CSI] and came up with eight significant consumer styles: (1) perfectionist, high-quality conscious (quality); (2) brand conscious (brand); (3) innovative and fashion conscious (innovative); (4) recreational or hedonistic shopping conscious (recreation); (5) price-value conscious (price); (6) impulsive/careless (impulse); (7) confused by overchoice (confused); and 8 ) habitual and brand loyal (loyal).

Despite the eight-dimensional structure being confirmed in the original study, it does not represent an ideal solution since some dimensions showed poor reliability (Tai, 2005). As a result, some country-specific structures of decision-making styles emerged in many studies (Mitchell \& Bates, 1998) that were conducted in divergent cultural situations without much modification in the instrument, and were restricted to student samples, although their findings generally confirmed the CSI structure (Tai, 2005). The consumer styles are described below, together with the hypotheses we test in our empirical study:

1) Quality: Perfectionist, high-quality conscious style belongs to consumers who search for the best quality in products, shopping more carefully, more systematically, or by comparison. They are not satisfied with the 'good enough' product (Sproles \& Kendall, 1986), so they are also considered perfectionists. Quality-conscious decision making style implies the perception of a hierarchy of quality levels (Leo et al., 2005). Hofstede's (2001) cultural dimension of power distance deals with inequality in prestige, wealth and power and Hofstede's (2001) cultural dimension of individualism deals with 'I' consciousness which one's identity is based on the individual. In this line of thought, cultures with higher power distance or that are highly individualistic would be more likely to engage in the quality conscious decision-making style. According to Hofstede (2001), Americans score the highest in the Individualism Index [IDV]. They possess varietyseeking tendencies due to the cultural assumption that choice is an indicative of the act of selfexpression (Kim \& Droplet, 2003). So, it is hypothesized that: 
$\mathrm{H}_{1}$ : Consumers from individualistic cultures are more quality conscious than consumers from collectivistic cultures (meaning that Americans are more quality conscious than Brazilians and Japanese).

2) Brand: Brand conscious style refers to a consumer's orientation towards the purchase of expensive and well-known brands. Brands are symbols of status and prestige (Leo et al., 2005), and members from individualistic cultures might buy brands that they perceive suitable to their personality, since brands are symbols that convey meanings to consumers and fashion consciousness for individuals from an individualistic cultural background (Manrai, Lascu, Manrai, $\&$ Babb, 2001). Thus, it is hypothesized that:

$\mathrm{H}_{2}$ : Consumers from individualistic cultures are more brand conscious than consumers from collectivistic cultures (meaning that Americans are more brand conscious than Brazilians and Japanese).

3) Innovative: Innovative and fashion conscious style refers to the predisposition a consumer has to buy new and different products and brands rather than remain with previous choices and consumption patterns (Venkatraman \& Price, 1990).

According to Hofstede (2001), the predisposition to purchase new and different products and brands is characterized by a high individualistic orientation. Consumers from individualistic cultures present higher propensity to risk and innovativeness than those from collectivistic cultures. In this sense, Americans, consumers who belong to the most individualistic culture (Hofstede, 1984), prefer rational thinking and are active information seekers. Collectivist cultures are conformity oriented and show a higher degree of group behavior and concern with promoting their continued existence, whereas people in individualistic societies are emotionally more detached from in-groups (other than immediate family) and place their personal goals, motivations and desires ahead of those of the ingroup (Kagitcibasi, 1997). Members of individualistic cultures focus on high public selfconsciousness, variety-seeking and less conformity behavior (Hofstede, 2001). So:

$\mathrm{H}_{3}$ : Consumers from individualistic cultures are more innovative than consumers from collectivistic cultures (meaning that Americans are more innovative than Brazilians and Japanese).

Moreover, more masculine societies place greater emphasis on wealth, success, ambition, material things and achievement, and the purchase of new items is one way for a person to assert his or her interests and to demonstrate wealth and success (Rogers, 1983). It is plausible that the greater emphasis that masculine societies place on material things (Hofstede, 1991) is expressed through a greater propensity to purchase new items (Mowen, 1995). In addition, more masculine societies place greater value on achievement, and there is evidence that achievement is related positively to innovativeness (Rogers, 1983). Thus, we hypothesized that:

$\mathrm{H}_{4}$ : Consumers from masculine cultures are more innovative than consumers from feminine cultures (meaning that Japanese are more innovative than Brazilians)

4) Recreation: A recreational or hedonistic shopping conscious style designates those facets of consumer behavior that relate to the multisensory, fantasy and emotive aspects of one's experience with products. Using a hedonistic consumption perspective, consumers see products not as functional units but rather as subjective symbols (Hirschman \& Holbrook, 1982). The literature suggests two propositions that might influence the hedonist consumer: consumers tend to treat a product according to the perspective learned from his/her ethnic group, and the amount of fantasy and emotionality encouraged/permitted in their members varies across cultures (Hirschman, 1981). Hedonism is related to the cultural dimension of individualism; individuals who belong to individualistic cultures are more likely to practice more hedonistic shopping (Hofstede, 2001). So, it is hypothesized that: 


\section{$\mathrm{H}_{5}$ : Consumers from individualistic cultures are more likely to practice hedonistic shopping than consumers from collectivistic cultures (meaning that Americans are more likely to practice hedonistic shopping than Brazilians and Japanese).}

5) Price: Price-value conscious style refers to the characteristic of trying the best product out of the money consumers are willing to spend. A study in 41 countries by Furnham, Kirkcaldy and Lynn (1994) demonstrates that different cultures can have different attitudes toward spending money. Furnham and Okamura (1999) concluded that money attitudes may be independent of income, in that different national cultures have different attitudes toward money and related behaviors, such as saving and spending (contrary to the economic theory that consumption determines savings, the need for saving may determine consumption) (Jain \& Joy, 1997).

Collectivistic cultures are expected to be more concerned with the status attributed to a given brand and more sensitive to maintaining prestige and status (Zhou \& Nakamoto, 2001); therefore, they may be willing to pay more in order to save face among their in-group members. Another Hofstede dimension that relates to price consciousness is masculinity: a masculine-oriented culture emphasizes ego-goals such as careers and money (Hofstede, 2001). Since price consciousness is related to individualistic or masculine cultures, and Americans are highly individualistic, while Japanese are highly masculine (Hofstede, 2001), it is hypothesized that:

$\mathbf{H}_{6}$ : Consumers from individualistic or masculine cultures are more price conscious than consumers from collectivist or feminine cultures (meaning that Americans or Japanese are more price conscious than Brazilians).

6) Impulse: Impulsive/careless style is characteristic of consumers who usually shop by impulse. Impulsive buying behavior is a sudden, compelling, hedonically complex purchasing behavior in which the rapidity of the impulse purchase decision process precludes thoughtful, deliberate consideration of all information and choice alternatives (Bayle \& Nancorrow, 1998). Impulsive consumer buying behavior is a widely recognized phenomenon. In the USA, for instance, it accounts for up to $80 \%$ of all purchases in certain product categories (Abrahams, 1997), and it has been suggested that purchases of new products result more from impulse purchasing than from prior planning.

Given that impulsiveness is related to sensation-seeking and emotional arousal (Rook, 1987), it is likely that people in collectivistic cultures learn to control their impulsive tendencies more than people from individualistic ones. In fact, children in collectivistic cultures are socialized to control their impulses at an early age (Ho, 1994). In individualistic cultures, people often ignore the potential negative consequences of their impulsive buying behavior (Rook, 1987), preferring to focus on the positive consequences of their actions and on their own feelings and goals. This may not be true for people from collectivistic cultures who are more likely to focus on the potential negative consequences of their behavior and the effect of their actions on in-group members (Triandis, 1995). Generally, the greater likelihood that people in collectivistic cultures will consider the negative consequences of their actions makes the suppression of the impulse trait-behavior relationship more probable (Kacen \& Lee, 2002). Following this line of thought, it is hypothesized that:

$\mathrm{H}_{7}$ : Consumers from individualistic cultures are more impulsive than consumers from collectivistic cultures (meaning that Americans are more impulsive than Brazilians and Japanese).

7) Confused: Confused style refers to the characteristic of being confused by overchoice. Consumer confusion is likely to become increasingly problematic for a variety of reasons: consumers are subjected to greater amounts of information, the number of products available is proliferating rapidly, product imitation strategies are increasing and technology is becoming ever more sophisticated. These factors, when combined, can make purchasing products, particularly technical ones, extremely confusing (Leek \& Kun, 2006). This can be particularly acute in high-involvement 
and complex purchases where consumers devote more time and effort to gathering and processing information and have a higher propensity to become overloaded (Mitchell \& Papavassiliou, 1999).

Leek and Kun (2006) carried out research on confusion in the mobile phone market in Thailand, and found that the same aspects of the industry (i.e. handsets, services and tariffs) caused confusion in the United Kingdom as well. In terms of confusion reduction, it was found that Thai consumers rely on friends and family to a greater extent to reduce confusion, which would be expected in a collectivistic culture. Consumers from collectivist cultures may be less confused by overchoice because members of such cultures will make decisions, most of the time, based on we rather than $\mathbf{I}$, consulting their close friends and family before making such decisions. Hence, we hypothesized that:

$\mathbf{H}_{8}$ : Consumers from individualistic cultures are more confused by overchoice than consumers from collectivistic cultures (meaning that Americans are more confused by overchoice than Brazilians and Japanese).

8) Loyal: Habitual and brand loyal style refers to consumers that have clearly defined in their minds what their favorite brand is. Few studies have evaluated the significance of cultural influence on consumer proneness to brand loyalty. Members of large power distance and collectivistic culture configurations tend to show a higher degree of brand loyalty. Consumers from cultures with high power distance tend to believe in large market-share brands, since the dominant brand has achieved what it has because it is the best and one should not question it (Palumbo \& Herbig, 2000). The power distance dimension is related to uncertainty avoidance (risk), meaning that it is more difficult for new entrants to compete in a market that belongs to a large power distance culture because their members are not willing to risk switching to an unknown brand.

Collectivistic cultures also tend to form brand loyal consumers since collective orientation has implications for consumer attitude formation and brand loyalty and ensures the survival of the dominant brand (Robinson, 1995). Conformity to the group plays a role: when an individual chooses another brand than the group-members or switches brands, it distinguishes this person from the group. So, it is preferable to choose the popular or perceived popular brands (Hofstede, 2001). Therefore, our final hypothesis is:

$\mathbf{H}_{9}$ : Consumers from collectivistic or large power distance cultures are more brand loyal than consumers from individualistic or small power distance cultures (meaning that Brazilians are more brand loyal than Americans or Japanese).

Table 3:

\section{Summary of Hypotheses}

\begin{tabular}{|c|c|c|c|c|c|c|c|c|}
\hline ơ & 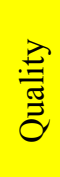 & $\begin{array}{l}\overrightarrow{\widetilde{E}} \\
\stackrel{\bar{n}}{n}\end{array}$ & 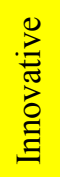 & 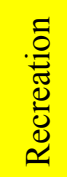 & $\stackrel{\mathscr{E}}{\Xi}$ & 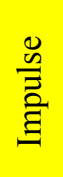 & $\begin{array}{l}\vec{D} \\
\sum_{0}^{2} \\
0 \\
0\end{array}$ & స్త్ర \\
\hline $\begin{array}{c}\text { PDI } \\
\text { IDV } \\
\text { MAS }\end{array}$ & $\mathrm{H}_{1}$ & $\mathrm{H}_{2}$ & $\begin{array}{l}\mathrm{H}_{3} \\
\mathrm{H}_{4}\end{array}$ & $\mathrm{H}_{5}$ & $\mathrm{H}_{6}$ & $\mathrm{H}_{7}$ & $\mathrm{H}_{8}$ & $\mathrm{H}_{9}$ \\
\hline UAI & & & & & & & & \\
\hline
\end{tabular}

Note. CSI = Consumer Style Inventory; PDI = Power Distance Index; IDV = Individualism Index; MAS = Masculinity Index; UAI = Uncertainty Avoidance Index. 
Table 3 summarizes the nine hypotheses presented above, linking Hofstede's cultural dimensions (Hofstede, 1984) and Sproles and Kendall's (1986) Consumer Style Inventory [CSI] framework. Next we present the empirical research method to test these hypotheses.

\section{METHOD}

Our main assumption is that consumer decision-making style is intrinsic with one's cultural background reflected in one's attitude and behavior. The self administered questionnaire contained 39 Likert-scaled items scored from 1 (strongly disagree) to 5 (strongly agree) composed in the Sproles and Kendall (1986) consumer decision-making style scale adapted to cell phone purchase. The English version of the questionnaire was translated to Portuguese and Japanese by a fluent bilingual translator, and then back-translated into English by another bilingual translator. Minor changes were made in the wording to clarify the semantics in the three versions. The questionnaire was pretested in the three countries to enhance its clarity, and it took approximately seven minutes to be fully responded.

The survey was conducted from August to September 2008 using convenience sampling in shopping malls and universities. In Brazil, the respondents were from the states of Parana, Rio de Janeiro and Sao Paulo; in the USA from the states of New Jersey and New York; and in Japan, from the prefectures of Aichi, Fukuoka, Hyogo and Osaka. We initially decided to perform the survey in China, in the cities of Beijing, Guangzhou and Shanghai, but we gave up due to data collection difficulties. Since our purpose was to analyze how culture influences the consumers' decision-making style, only respondents who were born and had lived more than half of their lifetime in their respective country of birth and whose parents were born in the same country as the respondent were considered in the sample. Furthermore, we considered only respondents that had purchased a cell phone in the past three years. A total of 348 questionnaires were received, but only 319 were considered valid: 108 from Brazil, 104 from the USA, and 107 from Japan. Among the three nationalities, the Japanese took the longest time to complete the questionnaire, as they generally took time thinking and reading carefully before answering each question. Brazilians generally were very friendly in answering the questionnaire: many still added personal comments about how they shopped for cell phones like 'I only buy cell phones on sale'.

For our purpose, the nationalities Brazilian, American and Japanese were treated as independent variables, and the eight decision-making styles of Sproles and Kendall (1986) were treated as the eight dependent variables. The dimensions of the Consumer Style Index [CSI] were measured by the following number of items: quality (eight, such as 'In general, I usually try to buy the best overall quality cell phone'), brand (five, such as 'I find well-known national brands of cell phones the best'), innovative (seven, such as 'A newly released model/brand cell phone is not something I would be eager to find out about'), recreation (five, such as 'I have fun shopping for cell phones'), price (three, such as 'I shop carefully to buy the best value cell phone for the money I spend'), impulse (five, such as 'I should plan better when shopping for a cell phone'), confused (three, such as 'The more I learn about cell phones, the harder it seems to choose the best'), loyal (three, such as 'I usually change the brand of the cell phones I buy').

Cronbach's alpha and item-to-total correlations were undertaken to assess the internal consistency of the instrument. Factor Analysis was used to determine its dimensionality. Items that had factor loadings lower than 0.3 were considered poor indicators and were removed from the analysis. Negative items had their scores reversed in the analysis. For each respondent, an aggregate score for each decision-making style was calculated from the item score (the sum of all items multiplied by their respective principal component). These mean scores were then compared for each style using Multivariate Analysis of Variance [MANOVA] using SPSS software. 


\section{RESULTS}

Table 4 presents the respondents' socio-demographic profile in the three countries, and Table 5 presents information about respondents' income, obtained in each national currency. We considered yearly income in the American and Japanese versions of the questionnaire and monthly income in the case of Brazil. Also, we built ranges for income information considering the countries' purchase power parity.

Table 4:

\section{Respondents’ Socio-Demographics Profile}

\begin{tabular}{|c|c|c|c|c|c|}
\hline & Variables / Countries & $\%$ & $\begin{array}{c}\text { Brazil } \\
(108) \\
29.1 \%\end{array}$ & $\begin{array}{c}\text { Japan } \\
(107) \\
28.8 \%\end{array}$ & $\begin{array}{c}\text { USA } \\
(104) \\
28.0 \%\end{array}$ \\
\hline \multirow{2}{*}{ Sex } & Female & 50.7 & 47 & 55 & 53 \\
\hline & Male & 49.3 & 61 & 52 & 51 \\
\hline \multirow{3}{*}{ Marital status } & Single & 54.4 & 65 & 55 & 55 \\
\hline & Married & 45.0 & 43 & 51 & 48 \\
\hline & Other & 0.5 & 0 & 1 & 1 \\
\hline \multirow{4}{*}{ Age (years) } & 25 or below & 26.1 & 38 & 21 & 20 \\
\hline & Between $26-35$ & 52.0 & 46 & 64 & 63 \\
\hline & Between 36 - 45 & 20.2 & 23 & 20 & 18 \\
\hline & Between 46 - 55 & 1.6 & 1 & 2 & 3 \\
\hline \multirow{4}{*}{ Education level } & Not a high school graduate & 2.4 & 0 & 3 & 4 \\
\hline & High school graduate or some college & 26.4 & 42 & 22 & 30 \\
\hline & Bachelor's graduate & 61.5 & 38 & 79 & 65 \\
\hline & Post-graduate and above & 9.7 & 28 & 3 & 5 \\
\hline \multirow{4}{*}{ Occupation } & Study only & 19.9 & 26 & 22 & 23 \\
\hline & Work only & 63.1 & 61 & 73 & 68 \\
\hline & Work and study & 16.7 & 21 & 11 & 13 \\
\hline & Retired & 0.3 & 0 & 1 & 0 \\
\hline
\end{tabular}

Table 5:

\section{Number of Respondents per Income Range}

\begin{tabular}{llllll}
\hline \multicolumn{1}{c}{ Brazil (monthly) } & \multicolumn{2}{c}{ Japan (yearly) } & \multicolumn{2}{c}{ USA (yearly) } \\
\hline$\leq \mathrm{R} \$ 1,500$ & 19 & $\leq ¥ 200,000$ & 21 & $\leq \mathrm{U} \$ 20,000$ & 21 \\
$\mathrm{R} \$ 1,501-3,000$ & 45 & $¥ 200,001-300,000$ & 42 & $\mathrm{US} \$ 20,001-30,000$ & 38 \\
$\mathrm{R} \$ 3,001-5,000$ & 18 & $¥ 300,001-450,000$ & 28 & $\mathrm{US} \$ 30,001-45,000$ & 26 \\
$\mathrm{R} \$ 5,001-10,000$ & 22 & $¥ 450,001-650,000$ & 7 & $\mathrm{US} \$ 45,001-65,000$ & 12 \\
$\geq \mathrm{R} \$ 10,001$ & 4 & $\geq ¥ 650,001$ & 9 & $\geq \mathrm{US} \$ 65,001$ & 7 \\
\hline
\end{tabular}


Factor Analysis via Principal Component Analysis was conducted on the 39 items to examine the suitability of the eight-factor model in observations from each country. Cronbach's alphas below 0.6 and item-to-total correlation below 0.3 were examined to check reliability of scales. After deleting 12 items of the original inventory we found a 27 -item inventory and six-factor solution (Table 6). The removal of items measuring price consciousness and impulsive shopping made it unable to analyze these two factors using MANOVA (Montemayor, 1996).

Table 6:

Reliability Results (Item-to-Total Correlations and Cronbach's Alpha)

\begin{tabular}{|c|c|c|c|c|c|c|}
\hline & \multicolumn{2}{|c|}{ Brazil } & \multicolumn{2}{|c|}{ Japan } & \multicolumn{2}{|c|}{ USA } \\
\hline & $\begin{array}{l}\text { Item-to-total } \\
\text { correlations }\end{array}$ & $\begin{array}{l}\text { Factor } \\
\text { Loadings }\end{array}$ & $\begin{array}{l}\text { Item-to-total } \\
\text { correlations }\end{array}$ & $\begin{array}{l}\text { Factor } \\
\text { Loadings }\end{array}$ & $\begin{array}{l}\text { Item-to-total } \\
\text { correlations }\end{array}$ & $\begin{array}{l}\text { Factor } \\
\text { Loadings }\end{array}$ \\
\hline Quality 4 & 0.73 & 0.84 & 0.61 & 0.77 & 0.84 & 0.89 \\
\hline Quality 5 & 0.49 & 0.63 & 0.31 & 0.40 & 0.68 & 0.76 \\
\hline Quality 7 & 0.57 & 0.71 & 0.64 & 0.79 & 0.73 & 0.81 \\
\hline Quality 16 & 0.55 & 0.69 & 0.53 & 0.63 & 0.71 & 0.78 \\
\hline Quality 22 & 0.56 & 0.69 & 0.53 & 0.69 & 0.66 & 0.75 \\
\hline Quality 24 & 0.64 & 0.77 & 0.53 & 0.70 & 0.84 & 0.89 \\
\hline Quality 39 & 0.35 & 0.47 & 0.63 & 0.76 & 0.73 & 0.80 \\
\hline $\begin{array}{l}\text { Cronbach's } \\
\text { Alpha }\end{array}$ & 0.82 & & 0.80 & & 0.92 & \\
\hline Brand 15 & 0.55 & 0.74 & 0.49 & 0.67 & 0.51 & 0.67 \\
\hline Brand 29 & 0.47 & 0.65 & 0.60 & 0.76 & 0.65 & 0.79 \\
\hline Brand 31 & 0.47 & 0.66 & 0.53 & 0.70 & 0.66 & 0.80 \\
\hline Brand 33 & 0.56 & 0.75 & 0.64 & 0.79 & 0.62 & 0.77 \\
\hline Brand 34 & 0.60 & 0.78 & 0.61 & 0.78 & 0.64 & 0.79 \\
\hline $\begin{array}{l}\text { Cronbach's } \\
\text { Alpha }\end{array}$ & 0.76 & & 0.79 & & 0.82 & \\
\hline Innovative 2 & 0.35 & 0.59 & 0.56 & 0.78 & 0.60 & 0.77 \\
\hline Innovative 23 & 0.40 & 0.67 & 0.39 & 0.62 & 0.63 & 0.80 \\
\hline Innovative 36 & 0.55 & 0.80 & 0.50 & 0.73 & 0.68 & 0.83 \\
\hline Innovative 37 & 0.58 & 0.82 & 0.67 & 0.85 & 0.76 & 0.88 \\
\hline $\begin{array}{l}\text { Cronbach's } \\
\text { Alpha }\end{array}$ & 0.68 & & 0.73 & & 0.83 & \\
\hline Recreation 3 & 0.35 & 0.59 & 0.71 & 0.84 & 0.72 & 0.85 \\
\hline Recreation 8 & 0.33 & 0.57 & 0.73 & 0.85 & 0.67 & 0.81 \\
\hline Recreation 27 & 0.65 & 0.84 & 0.73 & 0.86 & 0.71 & 0.85 \\
\hline Recreation 28 & 0.64 & 0.84 & 0.68 & 0.82 & 0.75 & 0.87 \\
\hline $\begin{array}{l}\text { Cronbach's } \\
\text { Alpha }\end{array}$ & 0.69 & & 0.86 & & 0.86 & \\
\hline Confused 6 & 0.51 & 0.80 & 0.64 & 0.88 & 0.33 & 0.62 \\
\hline Confused 32 & 0.47 & 0.77 & 0.34 & 0.59 & 0.50 & 0.82 \\
\hline Confused 35 & 0.46 & 0.76 & 0.71 & 0.91 & 0.67 & 0.90 \\
\hline
\end{tabular}


Table 6 (continued)

\begin{tabular}{lcccccc}
\hline & \multicolumn{2}{c}{ Brazil } & \multicolumn{2}{c}{ Japan } & \multicolumn{2}{c}{ USA } \\
\cline { 2 - 6 } & $\begin{array}{l}\text { Item-to-total } \\
\text { correlations }\end{array}$ & $\begin{array}{c}\text { Factor } \\
\text { Loadings }\end{array}$ & $\begin{array}{c}\text { Item-to-total } \\
\text { correlations }\end{array}$ & $\begin{array}{c}\text { Factor } \\
\text { Loadings }\end{array}$ & $\begin{array}{c}\text { Item-to-total } \\
\text { correlations }\end{array}$ & $\begin{array}{c}\text { Factor } \\
\text { Loadings }\end{array}$ \\
\hline $\begin{array}{l}\text { Cronbach's } \\
\text { Alpha }\end{array}$ & 0.67 & & 0.72 & & 0.68 & 0.73 \\
Loyal 17 & 0.49 & 0.75 & 0.55 & 0.77 & 0.48 & 0.86 \\
$\begin{array}{l}\text { Loyal 21 } \\
\text { Loyal 26 }\end{array}$ & 0.60 & 0.84 & 0.77 & 0.91 & 0.64 & 0.88 \\
$\begin{array}{l}\text { Cronbach's } \\
\text { Alpha }\end{array}$ & 0.63 & 0.86 & 0.69 & 0.87 & 0.67 & 0.76 \\
\hline
\end{tabular}

The multivariate statistic for MANOVA was found to be statistically significant (Wilk's Lambda = $0.653, \mathrm{~F}=4.81, \mathrm{p}<0,01)$. This result suggested that the mean vectors of predictor variables were different in at least one group (Brazil, Japan, or the USA). Levene test results also indicated that no violation of the homogeneity of variance $(\mathrm{p}<0,05)$ was observed in decision-making styles variables: quality $(0,002)$, brand $(0,007)$, innovative $(0,00)$, recreation $(0,003)$, confused $(0,005)$ and loyal $(0,008)$. Table 7 shows all mean scores derived from the three countries. Sheffe's tests also indicated particular pairs of group mean differences which are in bold in Table 7.

Table 7:

Cross-Cultural Differences in Decision-Making Styles

\begin{tabular}{lccccc}
\hline \multicolumn{1}{c}{ CSI Styles } & $\begin{array}{c}\text { Brazil } \\
\text { Mean }\end{array}$ & $\begin{array}{c}\text { Japan } \\
\text { Mean }\end{array}$ & $\begin{array}{c}\text { USA } \\
\text { Mean }\end{array}$ & Hypothesis & $\begin{array}{c}\text { Support for } \\
\text { hypotheses }\end{array}$ \\
\hline 1. Quality & 16.18 & 12.00 & 18.49 & $\mathrm{H}_{1}$ & Yes \\
2. Brand & 9.66 & 8.21 & 11.90 & $\mathrm{H}_{2}$ & Yes \\
3. Innovative & 7.16 & 8.14 & 10.66 & $\mathrm{H}_{3}$ and $\mathrm{H}_{4}$ & Yes \\
4. Recreation & 6.42 & $\mathbf{1 0 . 3 7}$ & $\mathbf{1 1 . 0 0}$ & $\mathrm{H}_{5}$ & Yes \\
5. Price & & & & $\mathrm{H}_{5}$ & Not tested \\
6. Impulsive & & & & $\mathrm{H}_{5}$ & Not tested \\
7. Confused & $\mathbf{6 . 4 1}$ & 7.78 & $\mathbf{6 . 3 0}$ & $\mathrm{H}_{8}$ & No \\
8. Loyal & 8.68 & $\mathbf{7 . 8 0}$ & $\mathbf{7 . 6 8}$ & $\mathrm{H}_{9}$ & Yes \\
\hline
\end{tabular}

H1 was supported as there were significant differences among the three cultures, and Americans proved to be the most quality conscious, followed by Brazilians and Japanese. H2 was supported, since Americans were significantly the most brand conscious, followed by Brazilians and Japanese. $\mathrm{H} 3$ and H4 were supported, meaning that Americans are more innovative than Japanese and Brazilians, in this order. H5 was supported in that Brazilians were revealed to practice less hedonistic cell phone shopping compared to Americans and Japanese. We could not test H6 and H7 due to the lack of reliability amongst the items. H8 was not supported, since there were no differences among the three cultures concerning confusion by overchoice. H9 was supported, since Brazilians were more brand loyal than Americans and Japanese. Next we present the implications of the results presented above and insights for further research. 


\section{FinAL REMARKS}

The findings show mixed evidence for the application of Hofstede's cultural dimensions to American, Brazilian and Japanese decision-making styles. It appears to be that even though a country receives a classification with cultural characteristics of Hofstede's typology of culture, these characteristics do not interact with each other. For instance, a quality conscious decision-making style relates to large power distance cultures but also to individualistic cultures. Therefore, if the power distance dimension stands out, Brazilians would be more quality conscious, and if individualism stands out, Americans would be more quality conscious.

Similarly, a brand conscious decision-making style is characteristic of large power distance and individualistic cultures. Thus, if the power distance dimension stands out, Brazilians would be the most brand conscious among the three countries, and if the individualism dimension stands out, Americans would be the most brand conscious. In this type of decision-making style, individualism stood out, so Americans are the most brand conscious.

Recreation conscious or hedonistic shopping refers to the extent to which shopping is considered pleasurable and fun. Hedonism is related to individualistic cultures, which matched with our results since Americans and Japanese were shown to practice more hedonistic shopping than Brazilians. Innovative consumers are prevalent characteristics of individualistic, masculine and low uncertainty avoidance cultures. Among the cultures, the Japanese scored higher in masculinity and in uncertainty avoidance; the USA scored higher in individualism and lower in uncertainty avoidance. Brazilians seem to belong to a collectivistic, masculine and high uncertainty avoidance society. This example shows clearly how these dimensions do not interact with each other. The results showed that Americans are the most innovative, followed by the Japanese and Brazilians. For this specific situation, the individualism dimension was more prominent, followed by masculinity and uncertainty avoidance.

Price-value and impulsive shopping decision-making styles could not be identified accurately because of reliability and validity reasons. Therefore we recommend that in future research the adapted scale we used be validated in countries other than the USA. It is important to perform studies in these two styles to check whether CSI is generalized to other populations or just to the population where the original CSI was applied (i.e. female college students in the USA).

Confusion by overchoice is a characteristic of an individualistic culture. Among the three cultures, the Japanese proved to be the most confused by overchoice, and the Americans, the least. Further research is necessary to analyze whether this situation occurred due the specific product (cell phone), since the literature indicates that individualistic cultures tend to have a more confused by overchoice decision-making style. A brand loyal decision-making style is a characteristic of a large power distance and collectivistic culture. Brazilians were shown to be the most brand loyal, followed by the Japanese and Americans. The results are in line with the theory which states that Brazilians belong to a larger power distance and more collectivistic culture than the Americans or Japanese.

There are some managerial implications that may be extracted from our research. Companies that are planning to enter new markets, but do not know them in depth may use the presented framework (relating Hofstede's cultural dimensions and Sproles and Kendall CSI) to try to understand and evaluate whether it is the best decision to draw companies initial offer in the specific markets. In addition, if a company plans to launch a product with very clear attributes (e.g. quality, brand, price etc.) in several countries, the company may decide which country to enter first. Our results show that there are differences in decision-making styles according to the culture a consumer belongs to. Companies present in different cultures might use different marketing mix approaches to their products since consumers respond differently to marketing stimuli.

Besides the convenience sampling, this article has limitations that may be overcome in future research. Stratified sampling techniques could be used to differentiate ethnic groups, such as African- 
American, Hispanics, Asian-Americans and Caucasian in the USA; or to differentiate gender or age ranges of a specific culture. In the past decades, cell phones have gone through many radical improvements, and have gained more functions. Each country has a distinct cultural background and different countries have different market needs. Companies may explore and pinpoint the expectations and desires that consumers from different countries are looking for. For instance, while Japanese consumers might be looking for cell phones which take high resolution pictures and play high definition videos, Brazilian consumers might be looking for cell phones with music player functions. In this line of thought, future studies may explore a way to reduce the gap by conciliating different cultures and different market demands.

Quality dimension is subject to interpretation, so future studies might explore different definitions of quality according to the culture in which individuals are embedded. Although Hofstede's cultural dimensions applied here are recognized worldwide, there are recent tools to measure culture developed by cross-cultural researchers such as Fons Trompenaars, Charles Hampden-Turner and Edward T. Hall, which could be considered in the future, mainly for the purposes of comparison.

Our research has some contributions to future research. For example, the questionnaire we rigorously adapted and translated into three languages may be a helpful tool for researchers. They also may take this article framework a little further to analyze specific cell phone companies' offers and explore the reasons for possible successes or failures in launching new cell phones in specific markets. Our theme has called attention to the impact of culture on consumers' decision-making style. Culture is a dynamic process and it is constantly changing over time. Cultural changes can be seen in the behavior, values, norms, thoughts and actions of a group of members. Likewise, their needs and desires change over time. Our empirical study may contribute to understanding the connection between national culture and decision-making styles, and may inspire further studies to explore this relationship.

\section{REFERENCES}

Abrahams, B. (1997). It's all in the mind. Marketing, 27, 31-33.

Bayley, G., \& Nancarrow, C. (1998). Impulsive purchasing: a qualitative exploration of the phenomenon. Qualitative Market Research, 1(2), 99-114.

Canabal, M. E. (2002). Decision making styles of young south Indian consumers: an exploratory study. College Student Journal, 26(1), 12-19.

Central Intelligence Agency (2009). The world factbook. Retrieved March 9, 2009, from http://www.cia.gov/library/publications/the-world-factbook/rankorder/2151 rank.html

Dawar, N., \& Parker, P. (1994). Marketing universals: consumers' use of brand name, price, physical appearance, and retailer reputation as signals of product quality. Journal of Marketing, 58(2), 81-95.

Dollinger, M. J., \& Danis, W. (1998). Preferred decision-making styles: a cross-cultural comparison. Psychological Reports, 82(3),755-762.

Engel, J. F., Blackwell, R. D., \& Miniard, P. W. (1993). Consumer behavior. Fort Worth, TX, USA: The Dryden Press.

Fan, J. X., \& Xiao, J. J. (1998). Consumer decision-making styles of young-adult Chinese. The Journal of Consumer Affairs, 32(2), 275-293. 
Furnham, A., \& Okamura, R. (1999). Your money or your life: behavioral and emotional predictors of money. Human Relations, 52(9), 1157-1177.

Furnham, A., Kirkcaldy, B., \& Lynn, R. (1994). National attitudes to competitiveness, money and work among young people: first, second and third world differences. Human Relations, 47(1), 119-132.

Hirschman, E. C. (1981). American Jewish ethnicity: its relationship to some selected aspects of consumer behavior. Journal of Marketing, 45(3), 102-110.

Hirschman, E. C., \& Holbrook, M. B. (1982). Hedonic consumption: emerging concepts, methods and propositions. Journal of Marketing, 46(3), 92-101.

Ho, D. Y. F. (1994). Cognitive socialization in confucian heritage cultures. In P. M. Greenfield \& R. R. Cocking (Eds.), Cross-cultural roots of minority child development (Chap. 14, pp. 285-314). Hillsdale, NJ: Lawrence Erlbaum Associates.

Hofstede, G. (1984). Culture's consequences: international differences in work-related values. Beverly Hills: Sage.

Hofstede, G. (1991). Cultures and organizations: software of the mind. London: McGraw-Hill.

Hofstede, G. (2001). Culture's consequences: comparing values behaviors, institutions, and organizations across nations. London: Sage.

Jain, A. K., \& Joy, A. (1997). Money matters: an exploratory study of the socio-cultural context of consumption, saving and investment patterns. Journal of Economic Psychology, 18(6), 649-675.

Kacen, J. J., \& Lee, J. A. (2002). The influence of culture on consumer impulsive buying behavior. Journal of Consumer Psychology, 12(2), 163-176.

Kagitcibasi, C. (1997). Individualism and collectivism. In J. W. Berry, M. H. Segall, \& C. Kagitcibasi, C. (Eds.), The handbook of cross-cultural psychology: Vol. 4. Social behavior and applications (2nd ed., pp. 1-49). Boston: Allyn and Bacon.

Kim, H. S., \& Droplet, A. (2003). Choice and self-expression: a cultural analysis of variety seeking. Journal of Personality and Social Psychology, 85(2), 373-382.

Lastovicka, J. L. (1982). On the validation of lifestyle traits: a review and illustration. Journal of Marketing Research, 19(1), 126-138.

Leek, S., \& Kun, D. (2006). Consumer confusion in the Chinese personal computer market. Journal of Product \& Brand Management, 15(3), 184-193.

Leo, C., Bennet, R., \& Hartel, C. (2005). Cross-cultural differences in consumer decision-making styles. Cross Cultural Management, 12(3), 32-61.

Lowe, A. C. T., \& Corkindale, D. R. (1998). Differences in cultural values and their effects on responses to marketing stimuli: a cross-cultural study between Australians and Chinese from the People's Republic of China. European Journal of Marketing, 32(9/10), 943-867.

Lynn, M., Zinkhan, G. M., \& Harris, J. (1993). Consumer tipping: a cross-country study. Journal of Consumer Research, 20(3), 478-488.

Lysonski, S., Durvasula, S., \& Zotos, Y. (1996). Consumer decision-making styles a multi-country investigation. European Journal of Marketing, 30(12), 10-21.

Manrai, L. A., Lascu, D. N., Manrai, A. K., \& Babb, H. W. (2001). A cross-cultural comparison of style in Eastern Europe emerging markets. International Marketing Review, 18(3), 270-285. 
Mitchell, V. W., \& Bates, L. (1998). UK consumer decision making style. Journal of Marketing Management, 14(1), 199-225.

Mitchell, V. W., \& Papavassiliou, V. (1999). Marketing causes and implications of consumer confusion. Journal of Product \& Brand Management, 8(4), 319-339.

Montemayor, E. F. (1996). Congruence between pay policy and competitive strategy in highperformance firms. Journal of Management, 22(6), 889-908.

Mowen, J. C. (1995). Consumer behavior (4th ed.). Englewood Cliffs: Prentice Hall.

Palumbo, F., \& Herbig, P. (2000). The multicultural context of brand loyalty. European Journal of Innovation Management, 3(3), 116-125.

Robinson, C. (1995). Asian culture: the marketing consequences. Journal of the Market Research Society, 38(1), 55-63.

Rogers, E. M. (1983). Diffusion of innovations (3rd ed.). New York: The Free Press.

Rook, D. W. (1987). The buying impulse. Journal of Consumer Research, 14(2), 189-199.

Roth, M. S. (1995). The effects of culture and socioeconomics on the performance of global brand image strategies. Journal of Marketing Research, 32(2), 163-175.

Schwartz, S. H. (1994). Beyond individualism/collectivism: new cultural dimensions of values. In U. Kim, H. C. Triandis, Ç. Kâgitçibasi, S. C. Choi, \& G. Yoon (Eds.), Individualism and collectivism: theory, method, and applications (Chap. 7, pp. 85-119). Thousand Oaks, CA: Sage Publications.

Smith, P. B., \& Schwartz, S. H. (1997). Values. In J. W. Berry, M. H. Segall, \& C. Kagitcibasi (Eds.), Handbook of cross-cultural psychology: Vol. 3. Social behavior and applications (2nd ed., pp. 77-118). Boston: Allyn \& Bacon.

Sproles, G., \& Kendall, E. L. (1986). A methodology for profiling consumers' decision- making styles. Journal of Consumer Affairs, 24(1), 134-147.

Tai, S. H. C. (2005). Shopping styles of working Chinese females. Journal of Retailing and Consumer Services, 12(3), 191-203.

Terpstra, V., \& David, K. (1991). The cultural environment of international business. Cincinnati: South-Western Publishing.

Triandis, H. C. (1995). Individualism and collectivism. Boulder: Westview.

Usunier, J. C. (1996). International marketing: a cultural approach (2nd ed.). Hempstead: PrenticeHall.

Venkatraman, M. P., \& Price, L. L. (1990). Differentiating between cognitive and sensory innovativeness: concepts, measurement, and implications. Journal of Business Research, 20(4), 293-315.

Westbrook, R. A., \& Black, W. C. (1985). A motivation-based shopping typology. Journal of Retailing, 61(1), 78-101.

Zhu, M., Quan, R., \& Xuan, K. (2006). The impact of Sino-western cultural differences on IT products consumption. Journal of Technology Management in China, 1(2), 159-173.

Zhou, Z., \& Nakamoto, K. (2001). Price perceptions: a cross-national study between American and Chinese young consumers. Advances in Consumer Research, 28(1), 161-168. 